\title{
Diet and Prey Selection of Alewives in Lake Michigan: Seasonal, Depth, and Interannual Patterns
}

\author{
Steven A. Pothoven* \\ Cooperative Institute Limnology and Ecosystem Research, \\ University of Michigan, Great Lakes Environmental Research Laboratory, \\ 1431 Beach Street, Muskegon, Michigan 49441, USA \\ Henry A. VANDERPLOEG \\ Great Lakes Environmental Research Laboratory, \\ National Oceanic and Atmospheric Administration, \\ 2205 Commonwealth Boulevard, Ann Arbor, Michigan 48105, USA
}

\begin{abstract}
To evaluate the current diet of alewives Alosa pseudoharengus and interactions with their prey in light of recent changes in Lake Michigan, we determined the seasonal diet and prey selectivity of large $(>100 \mathrm{~mm}$ total length) and small $(<100 \mathrm{~mm})$ alewives in southeastern Lake Michigan. Selectivity and diet were evaluated on a biomass basis for alewives collected near Muskegon, Michigan, during June, July-August, and October 1999-2001. Fish were sampled from three depth zones: shallow $(15-25 \mathrm{~m})$, transitional $(35-55 \mathrm{~m})$, and deep $(65-90 \mathrm{~m})$. Prey selectivity and diet patterns indicated that alewives had considerable flexibility in adjusting to prey availability, which varied by season, depth zone, and year. Although small copepods were an abundant prey item throughout the year and in all depth zones, they were mainly important in the diet (large and small alewives) in June and at the shallow stations, where many of the other prey types were not available. Despite declining numbers, Diporeia continued to be important for large alewives in spring, particularly at the transitional and deep stations, where their biomass was many times higher than that of other prey. During summer, large alewives selected either Bythotrephes longimanus or Mysis relicta in all depth zones and years. The diet of large alewives consisted mainly of Mysis in July 1999 and August 2001, whereas in August 2000 mainly Bosmina were eaten. During October, Mysis and Bythotrephes, along with large zooplankters (Daphnia spp. and large calanoid copepods), were selected and were most important in the diet of large alewives. In contrast, only the large zooplankton were selected and were important prey for the small alewives in fall. Annual, seasonal, and depth differences in prey biomass as well as differences in alewife size all influenced diet and selectivity patterns.
\end{abstract}

The alewife Alosa pseudoharengus has greatly altered the food web of Lake Michigan since its arrival in the 1940s. Alewives have been implicated in changes in zooplankton populations (Wells 1970; Evans and Jude 1986; Evans 1990) and in declines of some native fish species (Wells and McLain 1973). An aggressive salmonine stocking program that has provided a valuable recreational fishery brought alewives under control (Madenjian et al. 2002). Currently, alewives predominate the diet of stocked salmonines and trout in Lake Michigan (Stewart and Ibarra 1991; Madenjian et al. 1998).

Alewife diet and consumptive demands in Lake Michigan were studied extensively from their arrival in the 1940s through the late 1980s (Wells 1980; Crowder et al. 1981; Rand et al. 1995). However, there are few recent data on alewife diet, even

\footnotetext{
* Corresponding author: steve.pothoven@noaa.gov
}

Received June 17, 2003; accepted February 10, 2004 though the ecology of Lake Michigan is constantly changing. Zooplankton species composition has changed considerably since the early 1980s, although crustacean biomass has remained relatively constant (Makarewicz et al. 1995; Madenjian et al. 2002). Bythotrephes longimanus, a nonindigenous, predatory cladoceran, became established in the lake in 1986 (Evans 1988) and is both a competitor with alewives (Lehman and Caceres 1993; Vanderploeg et al. 1993; Schulz and Yurista 1999) as well as a potential food source (Mills et al. 1992; Rand et al. 1995; Rivier 1998). Finally, the burrowing amphipod Diporeia spp., a seasonally important prey item for alewives (Rand et al. 1995), has been declining in Lake Michigan since 1992 (Nalepa et al. 2000).

Few studies have examined alewife feeding preferences in the field even though size-selective feeding by alewives has been implicated in declines of large-bodied zooplankton in the Great Lakes (Wells 1970; Evans 1990). However, most 
diet studies have not been designed to simultaneously examine alewife diet relative to prey abundance. Collection of diet and prey abundance data allows calculations of prey selection necessary for predicting food consumption and diet under varying prey availability scenarios (Vanderploeg and Scavia 1979; Lechowicz 1982; Vanderploeg 1994) and provides insight into the feeding patterns of alewives, as well as how this species can alter the abundance or composition of invertebrate communities. Considering the influx of nonindigenous species and the dynamic nature of Lake Michigan, it is becoming increasingly important to understand the relationship between alewives and their prey as fishery managers take a more holistic approach to balancing salmonine stocking rates and alewife stocks.

The first goal of this study was to evaluate the seasonal diet patterns of alewives in southeastern Lake Michigan during 1999-2001 along a nearshore-to-offshore transect. We expected that, compared with previous studies, Bythotrephes would now be an important part of alewife diet, although we did not expect major changes in the overall contribution of zooplankton. We also expected that alternative prey, such as Mysis relicta or zooplankton, would replace Diporeia in the diet. A second goal was to determine prey selectivity of alewives. We expected that large pelagic prey would be selected if they were available.

\section{Methods}

Field collections were made in southeast Lake Michigan near Muskegon, Michigan, during 1999-2001. We sampled in June and July 1999 and in June, August, and October 2000 and 2001. We sampled along a $15-\mathrm{km}$ transect from nearshore to offshore at three depth zones: shallow (15-25 $\mathrm{m})$, transitional $(35-55 \mathrm{~m})$, and deep (65-90 m). The transitional depth zone historically had the highest densities of Diporeia and is also the region where zebra mussels Dreissena polymorpha are expanding most rapidly (Nalepa et al. 2000, 2001).

Alewives were collected during daylight from each depth zone during each season with a 7.6-m semiballoon bottom trawl (13-mm stretch mesh cod liner). Subsamples of at least 30 alewives (if available) were immediately frozen upon capture. In the laboratory, alewives were measured (total length; $\mathrm{mm}$ ) and their stomachs were removed and dissected. Diet analysis was done separately for small $(<100 \mathrm{~mm}$ total length) and large $(>100$ $\mathrm{mm})$ alewives. The size classifications generally correspond with age- 0 or yearling and adult alewives based on length frequency distributions.

All macroinvertebrate prey items (Mysis and Diporeia) and the large zooplankter Bythotrephes were removed from stomachs and counted, and the lengths of whole organisms were measured by means of a computer image-analysis system. Prey lengths of macroinvertebrates and Bythotrephes were converted to dry mass using weight-length regressions (Shea and Makarewicz 1989; Makarewicz and Jones 1990; T. Nalepa, Great Lakes Environmental Research Laboratory, personal communication). The dry weight of partially digested organisms that could not be measured was assumed to be equal to the mean weight of measured organisms. Paired eyes (Mysis and Diporeia) or bodies with eyespots (Bythotrephes) were used to enumerate partial prey items. All zooplankton in the diet other than Bythotrephes (e.g., Copepoda and Cladocera) were added to $10-25 \mathrm{~mL}$ of water and subsampled with a 1-mL Hensen-Stemple Pipette. Dilutions were chosen so that each subsample contained approximately 200 organisms. Zooplankton were classified as Bosmina spp., cyclopoid copepods, small calanoid copepods $(<2 \mathrm{~mm}$ total length exclusive of caudal setae), Daphnia spp. (mostly D. galeata mendotae), other cladocerans, and large calanoid copepods $(>2 \mathrm{~mm})$. Mean individual weights for the most abundant taxa in each grouping were derived from Hawkins and Evans (1979) and multiplied by total counts to obtain the biomass of each zooplankton group in the diet of each fish. Biomass of each prey group was summed across all individual fish from each sample period and depth, and diet composition was estimated as the percent of the total calculated dry weight from each respective collection. Diet composition was compared across seasons, years, and depth zones using log-linear modeling. Alewife size within each size grouping was compared across seasons, years, and depth zones using a generalized linear model. All statistical analyses were performed using SYSTAT (SPSS 1998).

To evaluate prey availability, we collected zooplankton, Mysis, and Diporeia in conjunction with all fish collections. Invertebrates were sampled at a shallow $(20 \mathrm{~m})$, transitional $(45 \mathrm{~m})$, and deep $(75 \mathrm{~m})$ station to characterize prey biomass within each depth zone where fish were collected. Prey availability was expressed as biomass per unit area to allow comparisons of pelagic prey with Diporeia (a benthic prey) to provide for comparisons of prey biomass across depth zones and to account for the nonuniform distribution of animals through 
the water column (Lehman 1991). Zooplankton were collected with triplicate vertical net tows at each station. Whole water column samples were taken from just above the bottom to the surface using a $0.5-\mathrm{m}$ diameter plankton net $(153-\mu \mathrm{m}$ mesh) during the day that fish were collected. Zooplankton were anesthetized with carbonated water and preserved in $4 \%$ sugar-buffered formalin. In the laboratory, zooplankton were added to 300$1,000 \mathrm{~mL}$ of water and subsampled with a $1-\mathrm{mL}$ Hensen-Stemple Pipette so that at least 200 organisms were counted for each sample. Zooplankton were classified into the same categories used for diet analysis, and numbers were converted into biomass using the same mean individual weights that were used for diet analysis. All Bythotrephes in zooplankton samples were counted and measured (Pothoven et al. 2001), and was biomass determined using a weight-length regression (Makarewicz and Jones 1990).

Triplicate samples of Mysis, which can only be captured effectively at night, were sampled at each station during the night of the fish collections using a 1-m-diameter plankton net $(1,000-\mu \mathrm{m}$ mesh) towed vertically from near the bottom to the surface at speeds of $0.5 \mathrm{~m} / \mathrm{s}$. Mysis were anesthetized with carbonated water and preserved in $4 \%$ sugarbuffered formalin. In the laboratory all mysids were counted and measured (Pothoven et al. 2000), and their biomass was determined using a weightlength regression (Shea and Makarewicz 1989). Mysis were assumed to be absent at the shallow station in 2000-2001, based on data collected in 1999, and because of limiting water temperatures at the bottom at the station (Shea and Makarewicz 1989). Diporeia were collected in triplicate at each station with a Ponar grab and washed through a $0.5-\mathrm{mm}$ Nitex mesh net. Retained material was preserved in 5\% formalin containing rose bengal stain. Diporeia were measured and their biomass was determined using weight-length regressions (T. Nalepa, Great Lakes Environmental Research Laboratory, personal communication). Biomass for each prey group was compared across seasons, years, and depth zones using a generalized linear model. A Bonferroni adjustment was used to account for the testing of multiple prey types that might not be independent, so $P$-values less than 0.006 were considered significant for prey biomass tests.

To determine prey selectivity, we used Vanderploeg and Scavia's (1979) selectivity coefficient, $W^{\prime}$, calculated as

$$
W_{i}^{\prime}=\left(r_{i} / p_{i}\right) /\left(r_{i} / p_{i}\right)_{\text {pref }},
$$

where relative prey abundance in the environment $(p)$ and diet $(r)$ were expressed in biomass units and $\left(r_{i} / p_{i}\right)_{\text {pref }}$ was the maximum value of $r_{i} / p_{i}$. The selectivity coefficient, $W^{\prime}$, varies between 0 for no ingestion of a prey type to 1 , the $W^{\prime}$ value for the most preferred prey type(s) (i.e. the prey type(s) with the maximum value of $\left.r_{i} / p_{i}\right)$. We speak of selectivity being high when $W^{\prime}$ is near 1 and low when it is near 0 . The selectivity coefficient, $W^{\prime}$, is unaffected by prey abundance or whether abundance is expressed as numbers or biomass and is easily understood as the relative mortality imposed by the predator on different prey types (Vanderploeg and Scavia 1979; Vanderploeg et al. 1984; Vanderploeg 1994). It has been especially useful for relating food selection to foraging strategy and feeding mechanisms and for models predicting prey consumption under various prey abundance scenarios (e.g., Vanderploeg 1981, 1994; Vanderploeg et al. 1984).

\section{Results}

\section{Prey Biomass}

In general, Diporeia had the highest available biomass in the environment, followed by small calanoid and cyclopoid copepods (Figure 1). The biomass of Mysis $(F=6.5 ; \mathrm{df}=2,34 ; P=0.004)$ and Bythotrephes, cyclopoid copepods, Bosmina, and Daphnia $(F>13.8$; df $=2,56 ; P<0.001)$ differed across seasons but did not for Diporeia, other cladocerans, and large and small calanoid copepods. The biomass of Mysis, Bythotrephes, Daphnia, and Bosmina was highest in the summer or fall but was highest in the spring for cyclopoid copepods. The biomass of Mysis $(F=7.1$; df $=$ 2, 34; $P=0.003$ ) and Bythotrephes, cyclopoid copepods, and Bosmina $(F>7.1$; df $=2,56 ; P<$ 0.002 ) differed across years, but that of all other prey groups did not. The availability of Mysis generally increased from 1999 to 2001 but decreased for cyclopoid copepods and Bythotrephes during the same period. The biomass of Bosmina was high in 2000 relative to 1999 and 2001. That of Diporeia $(F=42.7 ; \mathrm{df}=2,59 ; P<0.001)$, Mysis $(F=$ 15.6 ; $\mathrm{df}=1,34 ; P<0.001)$, cyclopoid copepods, small calanoid copepods, and Daphnia $(F>18.6$; $\mathrm{df}=2,56 ; P<0.001)$ differed across depth zones $(F>4.74, \mathrm{df}=1, P<0.01)$, but biomass of other cladocerans, Bythotrephes, large calanoid copepods, and Bosmina did not. The biomass of $\mathrm{Di}$ poreia, Mysis, and Daphnia was highest at the deep station, and small calanoid and cyclopoid copepod 


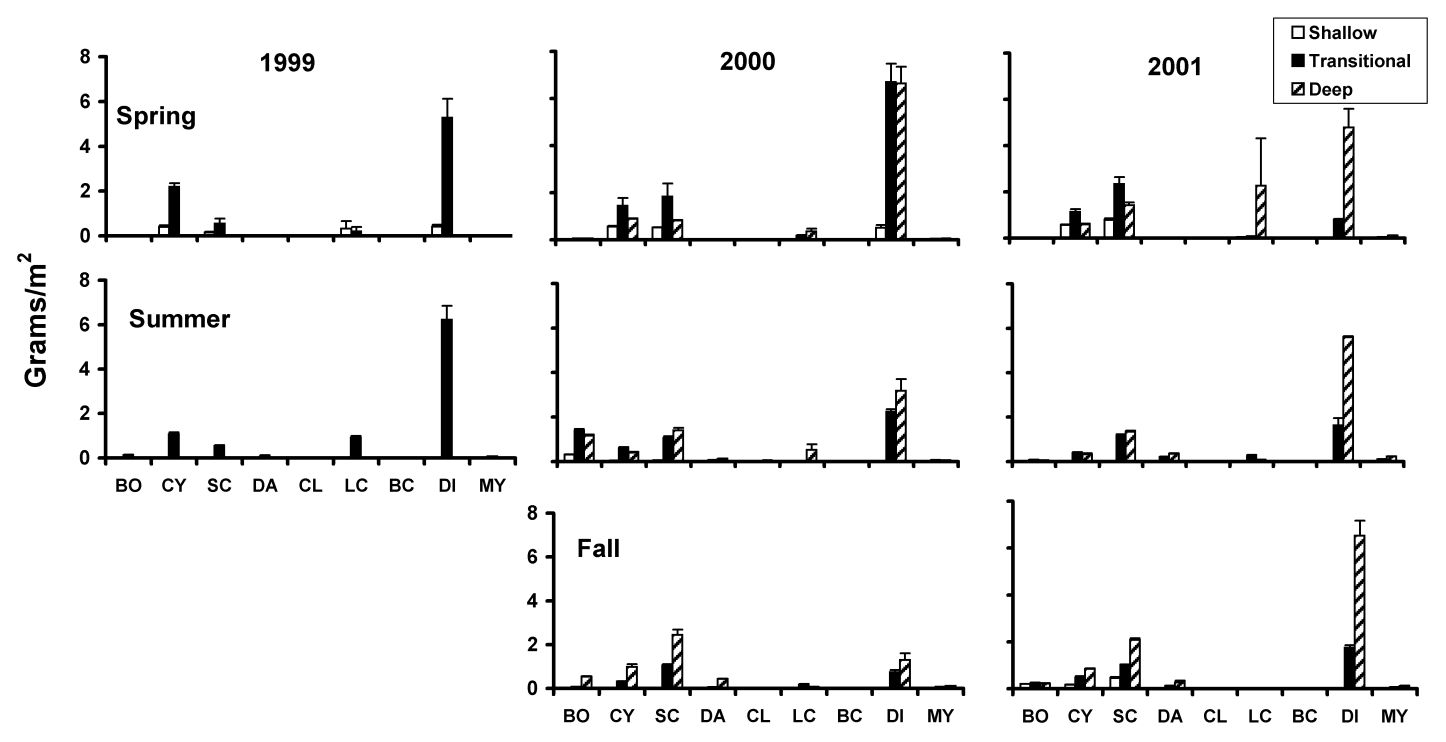

FIGURE 1.-Abundance $\left(\mathrm{g} / \mathrm{m}^{2}\right)$ of prey groups consumed by alewives in southeastern Lake Michigan, by three depth zones (shallow [15-25 m], transitional [35-55 m], and deep [65-90 m]) in spring, summer, and fall 19992001. Prey types are ordered in increasing size from left to right, where B0 = Bosmina, $\mathrm{CY}=$ cyclopoid copepods, $\mathrm{SC}=$ small calanoid copepods, $\mathrm{DA}=$ Daphnia, $\mathrm{CL}=$ other cladocerans, $\mathrm{LC}=$ large calanoid copepods, $\mathrm{BC}=$ Bythotrephes, DI = Diporeia, and MY $=$ Mysis. The thin vertical lines represent SEs.

biomass was higher at the transitional and deep stations than at the shallow station.

\section{Alewife Diet}

A total of 622 large and 172 small alewives that had food in their stomachs were used for diet analysis (Table 1). The size of large alewives varied across years $(F=177$; df $=2,685 ; P<0.01)$, seasons $(F=22 ; \mathrm{df}=2,685 ; P<0.01)$, and depth zones $(F=9$; df $=2,685 ; P<0.01)$. Large alewives were longer in 1999 and 2001 than in 2000. Alewives were also longer in the summer and at the deeper station. The size of small alewives also differed among years $(F=9 ; \mathrm{df}=2$, $178 ; P<0.01)$ and seasons $(F=18 ; \mathrm{df}=1,178$; $P<0.01)$ but not depth zones $(F=2$; df $=2$, $178 ; P=0.20)$. Small alewives were longer in the spring than in the fall and in 1999 than in 2001.

Log-linear modeling indicated that year, season, and depth zone were all required to describe the variation in diet composition for both large and small alewives $\left(\chi^{2}>17, \mathrm{df}=2, P<0.01\right)$. During June, cyclopoid and small calanoid copepods contributed most to the diet of large alewives in the shallow zone each year, although Diporeia also contributed to the diet in 2001 (Table 1). In the transitional and deep zones, Diporeia were consistently a major part of large alewife diet each year during June; small zooplankters and Mysis made substantial contributions in some instances. In the summer, small copepods and Diporeia made only minor contributions to large alewife diet, and Mysis were mainly eaten in summer 1999 and 2001 and Bosmina in 2000. Bythotrephes accounted for about a quarter of the diet in the transitional zone in August 2000. During October, large alewife diet consisted mainly of small zooplankters and Daphnia in the shallow zone (2001). In the transitional and deep zones, the diet was more varied, mainly consisting of large calanoid copepods, Mysis and Daphnia in 2000 and Mysis in 2001. The diet of small alewives was somewhat similar to that of large alewives in the June, when the diet consisted mainly of cyclopoid copepods and Diporeia (1999) or small calanoid copepods (2000; Table 1). Large calanoid copepods in 2000 and Daphnia in 2001 predominated the diet of small alewives in the October, but in contrast to large alewife, Mysis were rarely eaten.

\section{Alewife Selectivity}

During June in the shallow zone, large alewives selected small zooplankton each year (Bosmina, cyclopoid or small calanoid copepods; Figure 2). Diet selectivity varied at the transitional and deep zones during spring (e.g., large alewives strongly selected the largest prey, Mysis, in 1999 and 2001 and the smallest prey, Bosmina, in 2000). During 
TABLE 1.-Diet of small ( $<100 \mathrm{~mm}$ total length) and large $(>100 \mathrm{~mm}$ ) alewives (percent dry weight) for three depth zones (shallow [15-25 m], transitional [35-55 m; trans.], deep [65-90 m]) and three sampling periods (spring, summer, fall) in Lake Michigan during 1999-2001; $N=$ number of fish with food in their stomachs; TL = average length of alewives for each period.

\begin{tabular}{|c|c|c|c|c|c|c|}
\hline Date & Depth zone & $N$ & $\mathrm{TL}(\mathrm{mm})$ & Bosmina & Cyclopoids & Small calanoids \\
\hline \multicolumn{7}{|c|}{ Small } \\
\hline Jun 1999 & Shallow & 61 & 76 & 1 & 97 & 1 \\
\hline Jun 1999 & Trans. & 36 & 79 & $<1$ & 44 & $<1$ \\
\hline Jun 2000 & Shallow & 8 & 95 & 6 & 16 & 78 \\
\hline Oct 2000 & Trans. & 29 & 76 & 8 & $<1$ & 1 \\
\hline Oct 2000 & Deep & 21 & 71 & 2 & 0 & 1 \\
\hline Oct 2001 & Shallow & 17 & 70 & $<1$ & 18 & 29 \\
\hline \multicolumn{7}{|c|}{ Large } \\
\hline Jun 1999 & Shallow & 17 & 160 & $<1$ & 73 & 21 \\
\hline Jun 1999 & Trans. & 56 & 162 & $<1$ & 45 & 5 \\
\hline Jun 2000 & Shallow & 23 & 119 & 15 & 39 & 46 \\
\hline Jun 2000 & Trans. & 7 & 118 & 15 & 9 & 19 \\
\hline Jun 2000 & Deep & 56 & 121 & 8 & 12 & 21 \\
\hline Jun 2001 & Shallow & 29 & 144 & $<1$ & 13 & 31 \\
\hline Jun 2001 & Trans. & 28 & 136 & $<1$ & 1 & 5 \\
\hline Jun 2001 & Deep & 28 & 145 & $<1$ & $<1$ & $<1$ \\
\hline Jul 1999 & Trans. & 26 & 185 & $<1$ & $<1$ & $<1$ \\
\hline Aug 2000 & Shallow & 39 & 116 & 73 & $<1$ & $<1$ \\
\hline Aug 2000 & Trans. & 103 & 132 & 58 & 2 & 5 \\
\hline Aug 2000 & Deep & 60 & 143 & 70 & $<1$ & $<1$ \\
\hline Aug 2001 & Trans. & 6 & 164 & $<1$ & 0 & $<1$ \\
\hline Aug 2001 & Deep & 8 & 151 & $<1$ & 1 & $<1$ \\
\hline Oct 2000 & Trans. & 30 & 129 & $<1$ & $<1$ & $<1$ \\
\hline Oct 2000 & Deep & 32 & 132 & 1 & 0 & 1 \\
\hline Oct 2001 & Shallow & 8 & 123 & 9 & 16 & 41 \\
\hline Oct 2001 & Trans. & 36 & 140 & $<1$ & 5 & 12 \\
\hline Oct 2001 & Deep & 30 & 140 & $<1$ & $<1$ & $<1$ \\
\hline
\end{tabular}

summer, large alewives strongly selected either Bythotrephes or Mysis across all depth zones and years. Daphnia were selected during October in the shallow zone (2001), whereas in the transitional and deep zones (2000 and 2001), Mysis, large calanoid copepods, and Bythotrephes were all selected. Small alewives selected small zooplankton (Bosmina, cyclopoid and small calanoid copepods) in the spring and large zooplankton (large calanoid copepods or Daphnia) in the fall (Figure 3).

\section{Discussion}

The diet of alewives in 1999-2001 was fairly similar to the diet that has been observed since the 1960s (Wells 1980; Crowder et al. 1981; Hewett and Stewart 1989; Rand et al. 1995). Specifically, the diet was predominated by small copepods in the spring, larger cladocerans becoming more important in late summer and fall. Diporeia continued to be an important prey item for large alewives into late spring. There was some evidence that the importance of Mysis in the diet in summer may have increased over time (Hewett and Stewart 1989; Rand et al. 1995), but other factors, such as alewife size, can affect the importance of Mysis as a prey.

One important change in alewife diet over time was the increasing importance and selection of the invasive zooplanktor Bythotrephes, which was first found in Lake Michigan in 1986 and whose numbers have remained fairly stable through 2001 (Pothoven et al. 2001) even though adult, yearling, and young-of-year alewives began eating this new prey soon after its arrival (Rand et al. 1995; Branstrator and Lehman 1996). Currently, Bythotrephes appears to be strongly selected by adult alewives but not juveniles. The long tail spine of Bythotrephes prevents ingestion by very small fishes (about $4 \mathrm{~cm}$ ), and the aversion to ingestion of Bythotrephes decreases with increasing fish size (Barnhisel and Harvey 1995; Branstrator and Lehman 1996). The selection of Bythotrephes by large alewives is not surprising because Bythotrephes is also an important food source for fish in its native environments (Coulas et al. 1998; Rivier 1998).

Bythotrephes is only available as a food source during midsummer through late fall, but during that period they may alleviate some predation pressure on other preferred prey such as Mysis. Bytho- 
TABLE 1.-Extended.

\begin{tabular}{|c|c|c|c|c|c|c|}
\hline Date & Daphnia & Other cladocerans & Large calanoids & Bythotrephes & Diporeia & Mysis \\
\hline & \multicolumn{6}{|c|}{ Small } \\
\hline Jun 1999 & 0 & 0 & 0 & 0 & 0 & 0 \\
\hline Jun 1999 & 0 & 0 & 5 & 0 & 49 & 1 \\
\hline Jun 2000 & 0 & 0 & 0 & 0 & 0 & 0 \\
\hline Oct 2000 & 4 & 0 & 87 & 0 & 0 & 0 \\
\hline Oct 2000 & 4 & 0 & 93 & 0 & 0 & 0 \\
\hline \multirow[t]{2}{*}{ Oct 2001} & 52 & 0 & 0 & $<1$ & 0 & 0 \\
\hline & \multicolumn{6}{|c|}{ Large } \\
\hline Jun 1999 & 0 & 0 & 2 & 0 & 4 & 0 \\
\hline Jun 1999 & $<1$ & 0 & 28 & 0 & 18 & 4 \\
\hline Jun 2000 & 0 & 0 & 0 & 0 & 0 & 0 \\
\hline Jun 2000 & 0 & 0 & 0 & 0 & 57 & 0 \\
\hline Jun 2000 & $<1$ & 0 & 12 & 0 & 47 & $<1$ \\
\hline Jun 2001 & 6 & 0 & $<1$ & 0 & 49 & 0 \\
\hline Jun 2001 & 2 & 0 & 10 & 0 & 32 & 50 \\
\hline Jun 2001 & $<1$ & 0 & 0 & 0 & 67 & 32 \\
\hline Jul 1999 & 1 & 0 & 1 & 6 & 6 & 85 \\
\hline Aug 2000 & $<1$ & 3 & 0 & 9 & 1 & 13 \\
\hline Aug 2000 & 2 & 2 & 0 & 26 & 3 & 2 \\
\hline Aug 2000 & 5 & 0 & 1 & 7 & 15 & 2 \\
\hline Aug 2001 & 1 & 0 & 0 & $<1$ & 2 & 96 \\
\hline Aug 2001 & 5 & 0 & 0 & 12 & 7 & 74 \\
\hline Oct 2000 & 7 & 0 & 51 & 2 & 1 & 38 \\
\hline Oct 2000 & 25 & 0 & 43 & 2 & 2 & 26 \\
\hline Oct 2001 & 33 & 0 & 0 & 0 & 0 & 0 \\
\hline Oct 2001 & 3 & 0 & 0 & 2 & 0 & 78 \\
\hline Oct 2001 & $<1$ & 0 & 0 & $<1$ & 1 & 99 \\
\hline
\end{tabular}

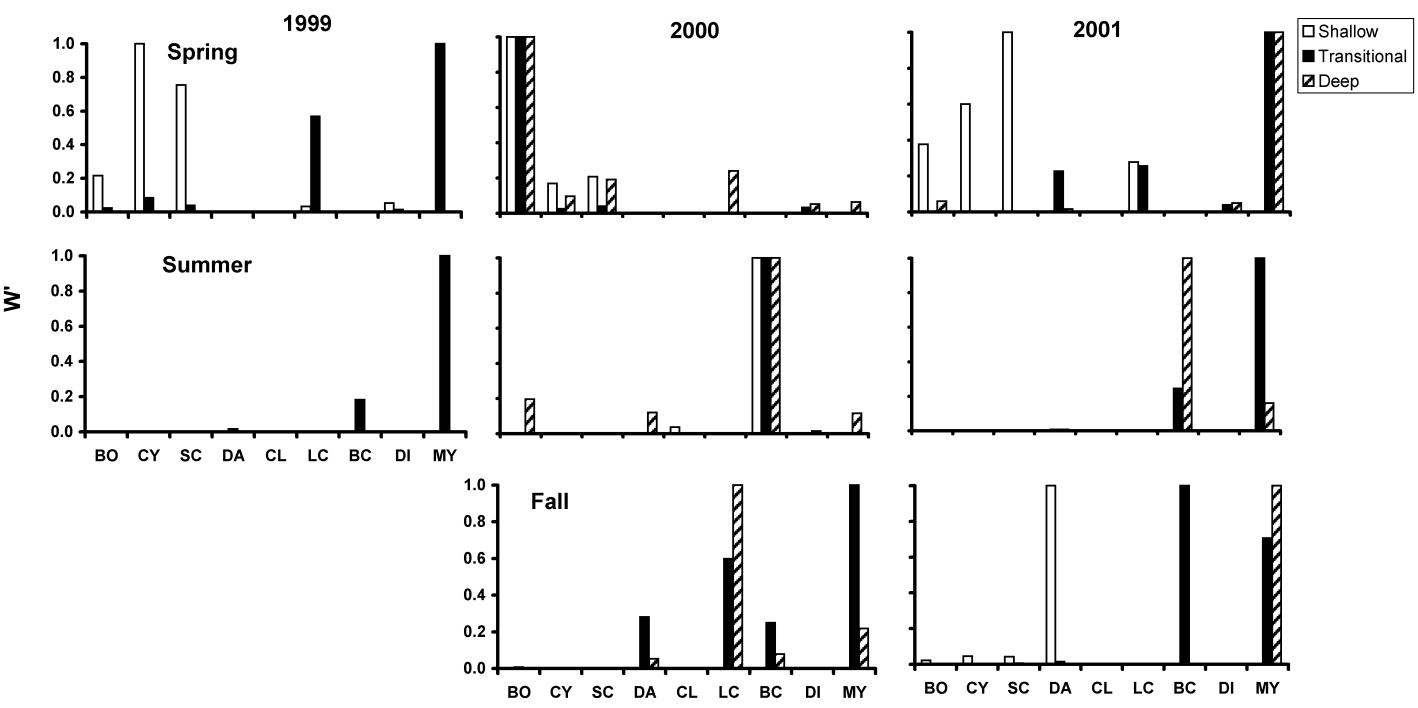

FIGURE 2.-Prey selectivity $\left(W^{\prime}\right)$ by large alewives $(>100 \mathrm{~mm}$ total length) captured from three depth zones (shallow [15-25 m], transitional [35-55 m], and deep [65-90 m]) of southeastern Lake Michigan in spring, summer, and fall 1999-2001. See Figure 1 for abbreviations. 


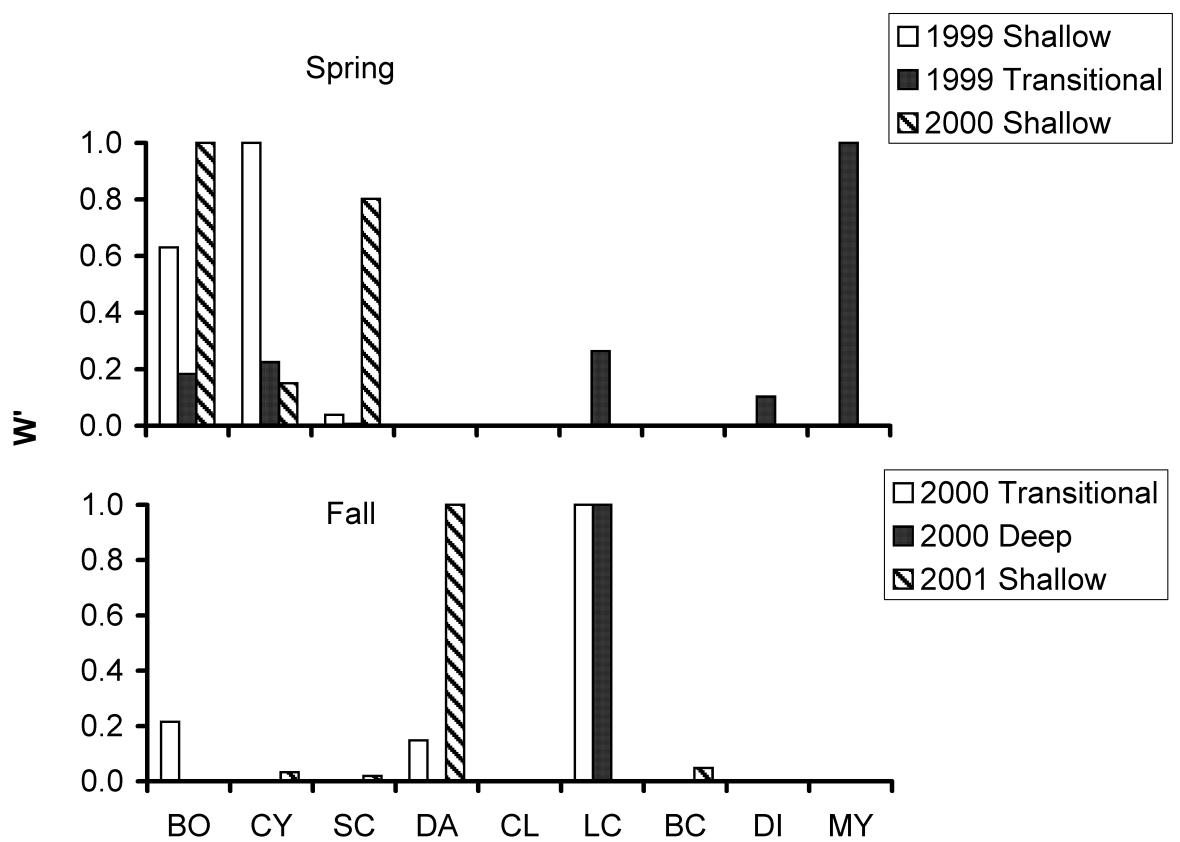

FIGURE 3.-Prey selectivity $\left(W^{\prime}\right)$ by small alewives $(<100 \mathrm{~mm}$ total length) captured from three depth zones (shallow [15-25 m], transitional [35-55 m], and deep [65-90 m]) of southeastern Lake Michigan in spring and fall 1999-2001. See Figure 1 for abbreviations.

trephes may also provide an alternative to largebodied zooplankters as a food source until alewives are large enough to consume Mysis, approximately age 3 for alewives in Lake Michigan (Hewett and Stewart 1989). For example, Bythotrephes were strongly selected and most important as a diet item in August 2000 when age 2 alewives predominated the population (S. Pothoven, unpublished data). In 1999 and 2001, when adult alewives were larger, Mysis were generally a more important prey type. Alewife predation on Bythotrephes may also indirectly reduce predation by Bythotrephes on small and large cladocerans (Vanderploeg et al. 1993). Most studies in the Great Lakes suggest that alewives play an important role in controlling abundance of Bythotrephes (Makarewicz and Jones 1990; Makarewicz et al. 1995; Vanderploeg et al. 2002), which is consistent with the strong selection we noted for Bythotrephes. This latter effect may be very important because Lehman and Branstrator (1995) estimated that 75\% of the secondary production of daphnids was lost by adding Bythotrephes to the food web.

Alewives are a behaviorally flexible species that can switch feeding tactics to match the available prey resources and prey preferences (Janssen 1980; Janssen et al. 1995). For example, during spring in the shallow zone, both small and large alewives tended to focus on small copepods, and the change in the environment from predominantly cyclopoid to calanoid copepods was also reflected in diet and selectivity patterns. However, the consumption of small copepods that we observed may have been related at least partly to the low abundance or absence of the other prey that were often preferred by alewives. For example, both sizeclasses of alewives were farther offshore in the springs of 1999 and 2000, and generally had strong selection for Mysis or large zooplankton, despite higher biomass of small copepods at the deeper sites. After June, selectivity for small copepods was low, and they were not a major diet item for either size-class of alewives. The change from copepods to other prey during the year and at deeper sites may reflect higher abundance of more preferred prey at the deeper sites and during the summer and fall. However, the change cannot entirely be separated from the fact that cyclopoid abundance decreased over the year, although small calanoid abundance did not vary seasonally. It seems unlikely that the change in high selectivity from copepods to other prey types is related to escape ability because Mysis and large copepods have more rapid escape responses than small copepods 
(Drenner et al. 1978; Link 1996; H. Vanderploeg, unpublished data). Other factors may include a general preference for larger prey types or differences in energy content of the prey.

Although large alewives often tended to select less abundant, large prey types, the smallest prey type, Bosmina, was selected (June) and contributed a large fraction of the diet (August) in all depth zones in 2000. Bosmina are less motile than small copepods (Drenner et al. 1978; Link 1996), so alewives might be more likely to utilize the abundant Bosmina rather than small copepods. Bosmina have historically been eaten by alewives in Lake Michigan (Wells 1970; Crowder et al. 1981) and were selected by alewives in inland Adirondack lakes (Hutchinson 1971). However, a study in Lake Ontario found that alewives avoided Bosmina (Strus and Hurley 1992). The importance of Bosmina as a prey type in 2000 appears related to their high abundance, although the smaller overall size of adult alewives in 2000 may have also been a factor.

Alewives have been implicated in declines of Daphnia spp. and large calanoid copepods in Lake Michigan (Wells 1970; Evans and Jude 1986; Evans 1990). Size-selective predation by juvenile alewives during late summer and early fall may be the main factor behind planktivory-driven changes in zooplankton populations (Crowder et al. 1987; Hewett and Stewart 1989). This is consistent with our finding that small alewives selected large zooplankters (Daphnia and large calanoid copepods) in the fall, even though other prey types were more abundant. Although in some instances large alewives selected large zooplankters in the fall, they also selected other large-bodied prey (Bythotrephes and Mysis) that small alewives did not.

Although most prey of alewives are pelagic, the benthic amphipod Diporeia was an important part of the diet of adult alewives in June. Alewives do not feed efficiently on the lake bottom (Janssen et al. 1995) and they mainly consume Diporeia in the spring when the species is in the water column (Mills et al. 1992). Recently, Diporeia populations began to decline dramatically in Lake Michigan (Nalepa et al. 2000). However, we did not see any consistent decrease in the importance of Diporeia as a diet item over the course of this study, even though during this period Diporeia declined by $100 \%$ in the shallow zone (none found) and by $85 \%$ in the transitional zone. If Diporeia completely disappear, alewives will probably be forced to increase consumption of Mysis or subsist on diets composed of small copepods during winter and spring (Hewett and Stewart 1989; Rand et al. 1995), which could affect growth, condition, and recruitment. Recent declines in condition of alewives may be linked to declines of Diporeia in Lake Michigan (Madenjian et al. 2002).

A potential problem with selectivity results is that fish and zooplankton are spatially patchy. As a result, what is observed in a zooplankton sample is not necessarily what is available to fish (Janssen 1980). However, the fairly consistent selectivity patterns across years provide some measure of power to our observations. Another potential problem is that differential gut passage rates could bias selectivity calculations (Gannon 1976). However, doubling the biomass of zooplankton eaten, which would simulate the effects of higher consumption of smaller prey due to faster digestion rates, did little to affect selectivity patterns. A related potential problem is that Bythotrephes spines may accumulate in fish stomachs (Branstrator and Lehman 1996). Because we only counted intact individuals or bodies, we used a conservative approach to evaluate the importance of Bythotrephes in the diet. Size-selective feeding within a prey group (Hutchinson 1971) could also affect our calculations somewhat because there could be differences in selectivity for the smallest and largest prey within our relatively broad prey categories. Finally, our diet results are biased toward daytime feeding patterns. However, because adult alewives feed heavily on Mysis at night (Wells 1980; Janssen and Brandt 1980), nighttime diet results would probably only corroborate our daytime results indicating the importance of Mysis in the diet.

The ability of alewives to use multiple feeding tactics may explain why this species has persisted in the changing environment of the Great Lakes since its arrival in the 1940s. Our results indicate that annual, seasonal, and depth zone differences in prey biomass and composition influence alewife diet. Additionally, differences in alewife size and age-structure affect diet and selectivity patterns. Changes in prey availability over time or water depths and alewife population structure need to be considered to accurately describe alewives in a food web context.

\section{Acknowledgments}

Assistance in the laboratory and field were provided by the crews of the RV Laurentian, RV Shenehon, D. Hondorp, J. Francis, E. Gaereminck, N. Lieberman, S. Rypma, A. Hauxwell, and B. Carlson. Funding was provided by the Great Lakes Fishery Trust and the National Oceanic and At- 
mospheric Administration. This is Great Lakes Environmental Research Laboratory contribution 1302.

\section{References}

Barnhisel, D. R., and H. A. Harvey. 1995. Size-specific fish avoidance of the spined crustacean Bythotrephes: field support for laboratory predictions. Canadian Journal of Fisheries and Aquatic Sciences 52:768-775.

Branstrator, D. K., and J. T. Lehman. 1996. Evidence for predation by young-of-the-year alewife and bloater chub on Bythotrephes cederstroemi in Lake Michigan. Journal of Great Lakes Research 22:917924.

Coulas, R. A., H. J. MacIsaac, and W. Dunlop. 1998. Selective predation on an introduced zooplanktor (Bythotrephes cederstroemi) by lake herring (Coregonus artedii) in Harp Lake, Ontario. Freshwater Biology 40:343-355.

Crowder, L. B., J. J. Magnuson, and S. B. Brandt. 1981. Complementarity in the use of food and thermal habitat by Lake Michigan fishes. Canadian Journal of Fisheries and Aquatic Sciences 38:662-668.

Crowder, L. B., M. E. McDonald, and J. A. Rice. 1987. Understanding recruitment of Lake Michigan fishes: the importance of size-based interactions between fish and zooplankton. Canadian Journal of Fisheries and Aquatic Sciences 44(Supplement 2):141-147.

Drenner, R. W., J. R. Strikler, and W. J. O'Brien. 1978. Capture probability: the role of zooplanktor escape in the selective feeding of planktivorous fish. Journal of the Fisheries Research Board of Canada 35: 1370-1373.

Evans, M. S. 1988. Bythotrephes cederstroemi: its new appearance in Lake Michigan. Journal of Great Lakes Research 14:234-240.

Evans, M. S. 1990. Large-lake responses to declines in the abundance of a major fish planktivore: the Lake Michigan example. Canadian Journal of Fisheries and Aquatic Sciences 47:1738-1754.

Evans, M. S., and D. J. Jude. 1986. Recent shifts in Daphnia community structure in southeastern Lake Michigan: a comparison of the inshore and offshore regions. Limnology and Oceanography 31:56-67.

Gannon, J. E. 1976. The effects of differential digestion rates of zooplankton by alewife, Alosa pseudoharengus, on determinations of selective feeding. Transactions of the American Fisheries Society 105: 89-95.

Hawkins, B. E., and M. E. Evans. 1979. Seasonal cycles of zooplankton biomass in southeastern Lake Michigan. Journal of Great Lakes Research 5:256-263.

Hewett, S. W., and D. J. Stewart. 1989. Zooplanktivory by alewives in Lake Michigan: ontogenetic, seasonal, and historical patterns. Transactions of the American Fisheries Society 118:581-596.

Hutchinson, B. P. 1971. The effect of fish predation on the zooplankton of ten Adirondack lakes, with particular reference to the alewife, Alosa pseudohar- engus. Transactions of the American Fisheries Society 100:325-335.

Janssen, J. 1980. Alewives (Alosa pseudoharengus) and ciscoes (Coregonus artedii) as selective and nonselective planktivores. Pages 580-586 in W. C. Kerfoot, editor. Evolution and ecology of zooplankton communities. University Press of New England, Hanover, New Hampshire.

Janssen, J., and S. B. Brandt. 1980. Feeding ecology and vertical migration of adult alewives (Alosa pseudoharengus) in Lake Michigan. Canadian Journal of Fisheries and Aquatic Sciences 37:177-184.

Janssen, J., W. R. Jones, A. Whang, and P. E. Oshel. 1995. Use of the lateral line in particulate feeding in the dark by juvenile alewife (Alosa pseudoharengus). Canadian Journal of Fisheries and Aquatic Sciences 52:358-363.

Lechowicz, M. J. 1982. The sampling characteristics of electivity indices. Oecologia 52:22-30.

Lehman, J. T. 1991. Causes and consequences of cladoceran dynamics in Lake Michigan: implications of species invasion by Bythotrephes. Journal of Great Lakes Research 17:437-445.

Lehman, J. T., and D. K. Branstrator. 1995. A model for growth, development, and diet selection by the invertebrate predator Bythotrephes cederstroemi. Journal of Great Lakes Research 21:610-619.

Lehman, J. T., and C. E. Caceres. 1993. Food web responses to species invasion by a predatory invertebrate: Bythotrephes in Lake Michigan. Limnology and Oceanography 38:879-891.

Link, J. 1996. Capture probabilities of Lake Superior zooplankton by an obligate planktivorous fish: the lake herring. Transactions of the American Fisheries Society 125:139-142.

Madenjian, C. P., T. J. DeSorcie, and R. M. Stedman. 1998. Ontogenic and spatial patterns in diet and growth of lake trout in Lake Michigan. Transactions of the American Fisheries Society 127:236-252.

Madenjian, C. R., G. L. Fahnenstiel, T. J. Johengen, T. F. Nalepa, H. A. Vanderploeg, G. W. Fleischer, P. J. Schneeberger, D. M. Benjamin, E. B. Smith, J. R. Bence, E. S. Rutherford, D. S. Lavis, D. M. Robertson, D. J. Jude, and M. P. Ebener. 2002. Dynamics of the Lake Michigan food web, 1970-2000. Canadian Journal of Fisheries and Aquatic Sciences 59:736-753.

Makarewicz, J. C., P. Bertram, T. Lewis, and E. H. Brown. 1995. A decade of predatory control of zooplankton species composition in Lake Michigan. Journal of Great Lakes Research 21:620-640.

Makarewicz, J. C., and H. D. Jones. 1990. Occurrence of Bythotrephes cederstroemi in Lake Ontario offshore waters. Journal of Great Lakes Research 16 : 143-147.

Mills, E. L., R. O’Gorman, J. DeGisi, R. F. Heberger, and R. A. House. 1992. Food of the alewife (Alosa pseudoharengus) in Lake Ontario before and after the establishment of Bythotrephes cederstroemi. Canadian Journal of Fisheries and Aquatic Sciences 49:2009-2019.

Nalepa, T. F., D. J. Hartson, J. Buchanan, J. F. Cavaletto, 
G. A. Lang, and S. J. Lozano. 2000. Spatial variation in density, mean size, and physiological condition of the holarctic amphipod. Journal of Freshwater Biology 43:107-119.

Nalepa, T. F., D. W. Schloesser, S. A. Pothoven, D. W. Hondorp, D. L. Fanslow, M. L. Tuchman, and G. W. Fleischer. 2001. First finding of the amphipod Echinogammarus ischnus and the mussel Dreissena bugensis in Lake Michigan. Journal of Great Lakes Research 27:384-391.

Pothoven, S. A., G. L. Fahnenstiel, and H. A. Vanderploeg. 2000. Population dynamics of Mysis relicta in southeastern Lake Michigan. Journal of Great Lakes Research 26:357-365.

Pothoven, S. A., G. L. Fahnenstiel, and H. A. Vanderploeg. 2001. Population dynamics of Bythotrephes cederstroemi in southeast Lake Michigan, 19951998. Freshwater Biology 46:1491-1503.

Rand, P. S., D. J. Stewart, B. F. Lantry, L. G. Rudstam, O. E. Johannsson, A. P. Goyke, S. B. Brandt, R. O'Gorman, and G. W. Eck. 1995. Effect of lakewide planktivory by the pelagic prey fish community in Lakes Michigan and Ontario. Canadian Journal of Fisheries and Aquatic Sciences 52:1546-1563.

Rivier, I. K. 1998. The predatory Cladocera (Onychopoda: Podonidae, Polyphemidae, Cercopagidae) and Leptodorida of the world. Backhuys Publishing, Leiden, The Netherlands.

Shea, M. A., and J. C. Makarewicz. 1989. Production, biomass, and trophic interaction of Mysis relicta in Lake Ontario. Journal of Great Lakes Research 15: 223-232.

Schulz, K. L., and P. M. Yurista. 1999. Implications of an invertebrate predator's (Bythotrephes cederstroemi) atypical effects on a pelagic zooplankton community. Hydrobiologia 380:179-193.

SPSS. 1998. SYSTAT 8.0. SPSS, Chicago, Illinois.

Stewart, D. J., and M. Ibarra. 1991. Predation and production by salmonine fishes in Lake Michigan, 1978-1988. Canadian Journal of Fisheries and Aquatic Sciences 48:909-922.

Strus, R. H., and D. A. Hurley. 1992. Interaction be- tween alewife (Alosa pseudoharengus), their food, and phytoplankton biomass in the Bay of Quinte, Lake Ontario. Journal of Great Lakes Research 18: 709-723.

Vanderploeg, H. A. 1981. Seasonal particle-size selection by Diaptomus sicilis in offshore Lake Michigan. Canadian Journal of Fisheries and Aquatic Sciences 38:504-517.

Vanderploeg, H. A. 1994. Zooplankton particle selection and feeding mechanisms. Pages 205-234 in R. S. Wotton, editor. The biology of particles in aquatic systems. Lewis Publishers, Ann Arbor, Michigan.

Vanderploeg, H. A., J. R. Liebig, and M. Omair. 1993. Bythotrephes predation on Great Lakes' zooplankton measured by an in situ method: implications for zooplankton community structure. Archiv für $\mathrm{Hy}$ drobiologie 127:1-8.

Vanderploeg, H. A., T. F. Nalepa, D. J. Jude, E. L. Mills, K. T. Holbeck, J. R. Liebig, I. A. Grigorovich, and H. Ojaveer. 2002. Dispersal and emerging ecological impacts of Ponto-Caspian species in the Laurentian Great Lakes. Canadian Journal of Fisheries and Aquatic Sciences 59:1209-1228.

Vanderploeg, H. A., and D. Scavia. 1979. Calculation and use of selectivity coefficients of feeding: zooplankton grazing. Ecological Modelling 7:135-149.

Vanderploeg, H. A., D. Scavia, and J. R. Liebig. 1984. Feeding rate of Diaptomus sicilis and its relation to selectivity and effective food concentration in algal mixtures in Lake Michigan. Journal of Plankton Research 6:919-941.

Wells, L. 1970. Effects of alewife predation on zooplankton populations in Lake Michigan. Limnology and Oceanography 15:556-565.

Wells, L. 1980. Food of alewives, yellow perch, spottail shiners, trout-perch, and slimy and fourhorn sculpins in southeastern Lake Michigan. U.S. Fish and Wildlife Service, Technical Paper 98, Ann Arbor, Michigan.

Wells, L., and A. L. McLain. 1973. Lake Michigan: man's effects on native fish stocks and other biota. Great Lakes Fisheries Commission, Technical Report 20, Ann Arbor, Michigan. 